Kumawula, Vol. 2, No.1, April 2019, Hal 1 - 11 DOI:http://10.24198/kumawula.v1i3. 23533 ISSN 2620-844X (online)

Tersedia online di http://jurnal.unpad.ac.id/kumawula/index

\title{
PELATIHAN PEMASARAN PRODUK OLAHAN TELO UNGU DI DESA WONOSARI KECAMATAN WONOSARI GUNUNG KAWI KABUPATEN MALANG
}

\author{
Farida Nur Kumala ${ }^{1}$, Muhammad Nur Hudha ${ }^{2}$, Sudi Dul Aji ${ }^{3}$ \\ 1,2,3 Universitas Kanjuruhan Malang \\ *faridankumala@unikama.ac.id
}

\begin{abstract}
ABSTRAK
Tujuan program kemitraan masyarakat ini adalah melakukan pelatihan pemasaran produk olahan telo ungu di Desa Wonosari Kecamatan Wonosari Kabupaten Malang. Sebelumnya telah dilakukan pelatihan tentang pengolahan dan produksi telo ungu menjadi beberapa produk di antaranya brownies, bakpia dan stik telo ungu. Namun dari kegiatan tersebut terdapat kendala yakni pemasaran yang masih bersifat sederhana dan ruang lingkup local daerah mitra. Metode yang digunakan pada kegiatan kemitraan pada masyarakat ini dilakukan melalui tiga tahapan yakni persiapan, pelaksanaan dan evaluasi program. Program kemitraan pada masyarakat ini diikuti oleh 20 orang warga Desa Wonosari Kecamatan Wonosari Kabupaten Malang. Pelatihan dilakukan melalui pemasaran secara online dan offline. Hasil pelatihan didapatkan program pemasaran secara online dan offline. Pemasaran secara online dilakukan melalui media sosial seperti Instagram, Facebook dan Whatsapp.
\end{abstract}

Keywords: Gunung Kawi; Pelatihan; Pemasaran; Telo Ungu

\section{PURPLE SWEET POTATO PRODUCT MARKETING TRAINING IN WONOSARI VILLAGE. WONOSARI DISTRICT, GUNUNG KAWI, MALANG REGENCY}

\begin{abstract}
The purpose of this program is to conduct training in marketing of processed purple sweet potato products in the village of Wonosari, Wonosari District, Malang Regency. Previously there had been training on the manufacture and production of purple sweet potato into several products, such as brownies, bakpia and purple sweet potato stick. However, from these activities, promotions were simple. The method used in partnership activities in the community were carried out through three stages of program preparation, implementation and evaluation. The instrument used observation and interview. This partnership program in the community was attended by 20 Wonosari village residents, Wonosari Malang Regency. Training was done through online and offline marketing. Training programs obtained online and offline marketing. Online marketing was done through social media such as Instragram, Facebook and Whatsapp.
\end{abstract}

Keywords: Gunung Kawi; Marketing; Purple sweet potato;Training Program 


\section{Pendahuluan}

Pertumbuhan ekonomi Indonesia salah satunya berkembang melalui Usaha kecil dan Menengah (UKM) (Jaidan Jauhari, 2010). Hal ini dikarenakan daya serap UKM terhadap tenaga kerja yang sangat besar dan dekat dengan rakyat kecil ((Munir, 2006); Kuncoro, 2008; Sripo, 2010) selain itu UKM menyebabkan perekonomian yang kuat, karena terbukti bahwa UKM paling tahan terhadap krisis (Kuncoro, 2008). Usaha Kecil dan Menengah (UKM) adalah suatu bentuk usaha yang dilihat dari skalanya usaha rumah tangga dan usaha kecil hanya mempunyai jumlah pegawai antara 1- 19 orang. Sementara usaha menengah mempunyai pegawai antara 20-99 orang ((Sulistyo, 2010); (Maryanti, 2017)). UKM adalah salah satu jenis usaha milik perorangan, badan usahanya berbadan hukum maupun tidak berbadan hukum. Badan usaha ini selain berdiri sendiri dan bukan merupakan anak perusahaan atau cabang perusahaan yang dimiliki, dikuasai atau berafiliasi baik langsung maupun tidak langsung.

Usaha Mikro Kecil dan Menengah (UMKM) merupakan salah satu bagian penting dari perekonomian suatu Negara ataupun suatu daerah, tidak terkecuali di Indonesia. Pengembangan sektor Usaha Mikro Kecil dan Menengah (UMKM) memberikan makna tersendiri pada usaha peningkatan pertumbuhan ekonomi serta dalam usaha menekan angka kemiskinan suatu negara. Pertumbuhan dan pengembangan sektor UMKM sering diartikan sebagai salah satu indikator keberhasilan pembangunan, khususnya bagi negara-negara yang memiliki pendapatan perkapita yang rendah (Wibowo, Arifin, \& Sunarti, 2015).

Namun permasalahan utama yang sering dikeluhkan oleh UKM adalah kemampuan dalam hal pemasaran (Hafsah, 2004; Kuncoro, 2008; Kurniawan, 2009; Supardi, 2009). Hal ini disebabkan pemasaran memerlukan biaya tinggi, misalnya membuka cabang baru, ikut pameran, pembuatan dan penyebaran brosur dan sebagainya.

Pemasaran adalah suatu proses sosial dan manajerial yang di dalamnya individu dan kelompok mendapatkan yang mereka butuhkan dan inginkan dengan menciptakan, menawarkan, dan mempertukarkan produk yang bernilai kepada pihak lain (Kottler, 2002). Ditambahkan (Winarto, 2011) pemasaran merupakan interaksi yang berusaha menciptakan hubungan pertukaran yang dilakukan sebelum maupun sesudah terjadinya proses pertukaran demi terciptanya kepuasan baik pembeli maupun penjual.

Tujuan dari pemasaran adalah menarik pelanggan baru dengan menciptakan suatu produk yang sesuai dengan keinginan konsumen, menjanjikan nilai superior, menetapkan harga menarik, mendistribusikan produk dengan mudah, mempromosikan secara efektif serta mempertahankan pelanggan yang sudah ada dengan tetap memegang prinsip kepuasan 
pelanggan(Putri, 2017). Dasar pemikiran pemasaran dimulai dengan adanya kebutuhan (needs), keinginan (wants), dan permintaan (demands) konsumen terhadap suatu produk (barang, jasa, gagasan); sehingga produk tersebut memiliki nilai, biaya dan kepuasan. Dalam memenuhi hal tersebut dibutuhkan kegiatan pertukaran dan transaksi yang dilakukan di pasar. Dalam Pasar terdapat kegiatan pemasaran, ada pemasar dan calon pembeli. Dapat dijabarkan pada gambar 1.

Gambar 1. Gambar Konsep Pemasaran Philip Kottler (2002)

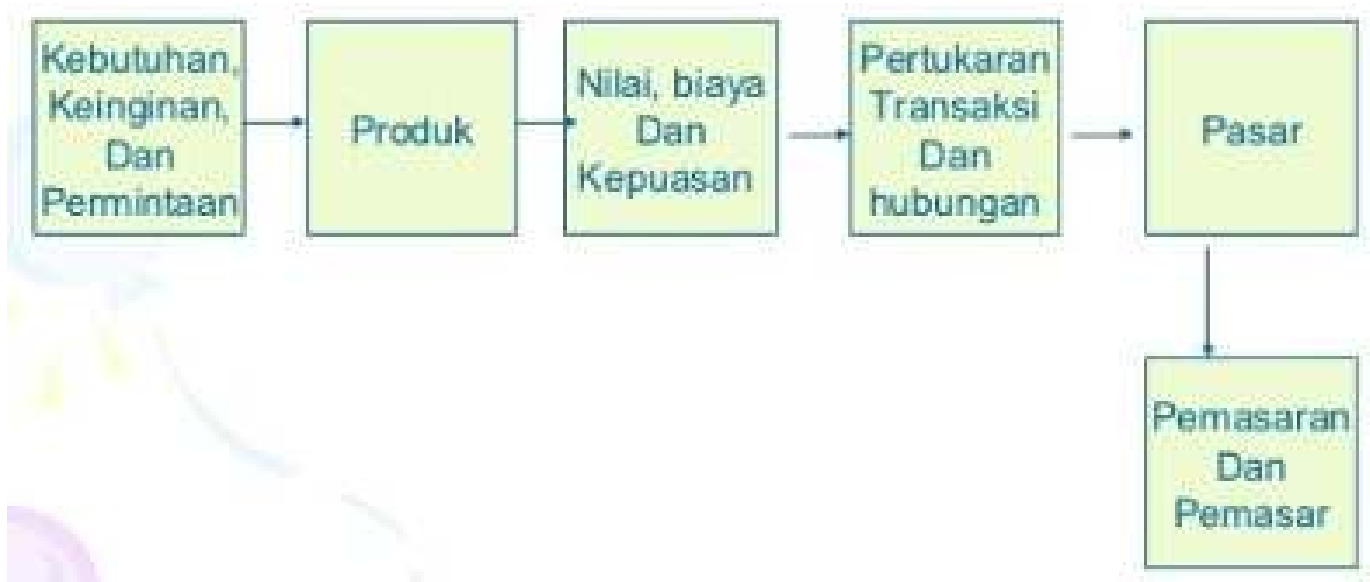

Dalam pemasaran, kegiatan diarahkan untuk memenuhi kebutuhan dan keinginana konsumen melalui kegiatan pertukaran. Kegiatan ini merupakan kegiatan perpindahan/ penyaluran baik benda maupun jasa dari produsen maupun konsumen melalui beberapa lembaga atau pelaku pemasaran, termasuk di dalamnya aktivitas yang menghasilkan perubahan bentuk untuk mempermudah penyaluran sehingga dapat memberikan kepuasaan yang lebih tinggi kepada konsumen(Febriani, 2013).

Pentingnya pemasaran dalam kegiatan ekonomi sangat menentukan keberhasilan kegiatan ekonomi masyarakat. Namun kembali lagi masih banyak kegiatan ekonomi masyarakat masih belum mampu melakukan pemasaran dengan baik karena terkendala beberapa hal. Permasalahan juga terjadi pada salah satu UKM yang ada di Malang yaitu UKM Telo Ungu Gunung Kawi. UKM Telo Ungu Gunung Kawi ini telah memperoduksi produk olahan telo Gunung Kawi diantaranya stik, bronies dan bakpia telo ungu. Namun dari kegiatan yang telah berjalan diketahui terdapat permasalahan khususnya dalam hal pemasaran. Dalam hal pemasaran mitra mengalami kesulitan untuk menawarkan produk ke tempat yang lebih luas.

Mengatasi permasalahan tersebut dapat digunakan internet sebagai sarana dalam melaksankan pemasaran. Hal ini disebabkan biaya yang dikeluarkan murah dan lebih cepat dengan jangkuan lebih luas (Supardi, 2009). Didukung data perilaku penggunaan internet 
Indonesia tahun 2018 oleh Asosiasi Penyelenggara Jasa Internet Indonesia (APJII) menyampaikan bahwa dari total populasi sebanyak 264 juta jiwa penduduk Indonesia, ada sebanyak 171,17 juta jiwa atau sekitar 64,8 persen yang sudah terhubung ke internet. Tersebar di seluruh Indonesia yang ditunjukkan pada gambar 2 dengan komposisi tujuan penggunaan internet pada gambar 3 .

Gambar 2. Kontribusi pengguna internet per wilayah dari seluruh pengguna Internet.

\section{Kontribusi Pengguna intemet oer Wilayah dan} Seluruh Pengeuna internet

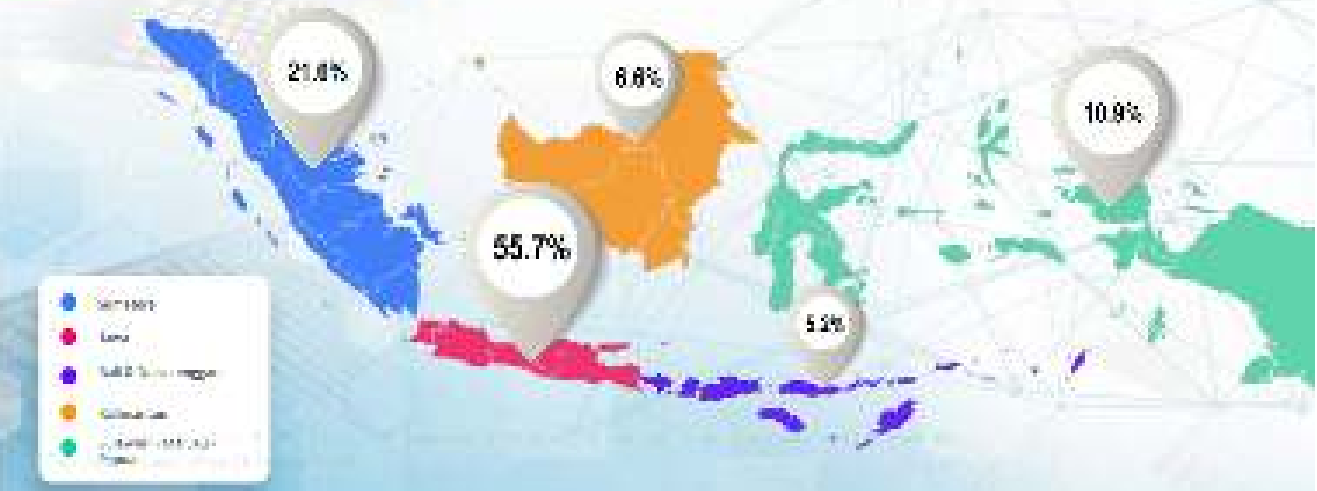

Gambar 3. Komposisi penggunaan Internet Indonesia Tahun 2018

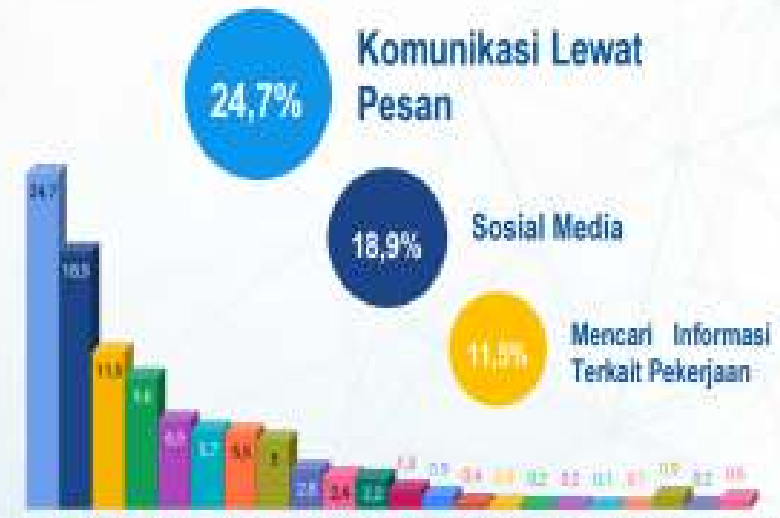

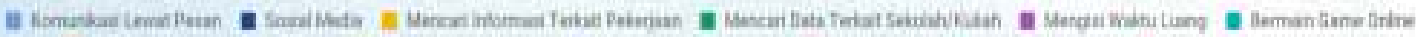

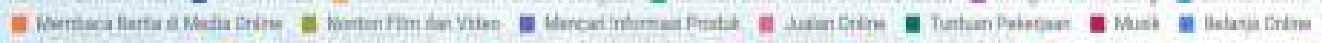

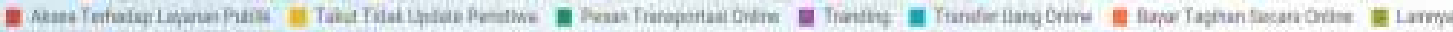

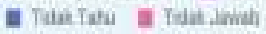

Berdasarkan gambar 3 komposisi penggunaa internet di Indonesia yang teratas adalah komunikasi sebesar 24,7\%, social media 18,9\% dan mencari informasi terkait pekerjaan 11,5\%, belanja online dll. Berdasarkan data tersebut dapat kita tarik kesimpulan bahwa penggunaan internet lebih banyak pada komunikasi sosial dan media sosial di antaranya facebook, Instagram, maupun Youtube (Sulistyadi \& Kurniasari, 2018). Ditunjukkan gambar 4. 
Gambar 4. Konten media social yang sering dikunjungi Masyarakat
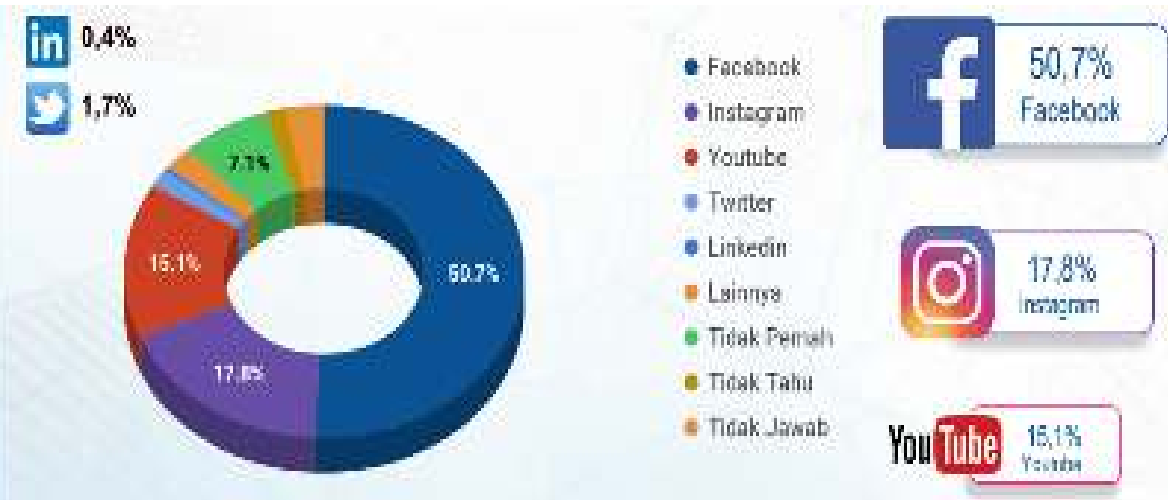

Sehingga jika dikaitkan dengan kegiatan pemasaran maka akan sangat baik jika pemasaran diarahkan pada keduanya misalnya Whatsapp dan media social dapat berupa Instagram dan facebook. Berdasarkan hal tersebut dibutuhkan kegiatan pelatihan dan pendampingan kegiatan pemasaran melaluisecara online dan offline melalui program kemitraan Masyarakat dengan tujuan dapat meningkatkan kegiatan pemasaran produk yang telah dikembangkan oleh UKM Telo ungu Gunung Kawi.

\section{Metode}

Program kemitraan masyarakat ini dilakukan melalui 3 tahapan kegiatan, yakni:

Gambar 5. Pelaksanaan kegiatan PKM

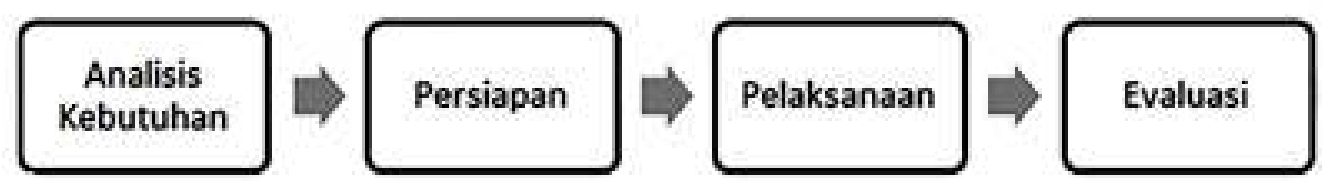

Pada gambar 5 dapat dijabarkan sebagai berikut:

\begin{tabular}{|l|l|}
\hline Kegiatan & \multicolumn{1}{c|}{ Jabaran Kegiatan } \\
\hline Knalisis & $\begin{array}{l}\text { Analisis kebutuhan dilakukan untuk mengetahui permasalahan yang terjadi } \\
\text { pada mitra. Analisis ini dilakukan melalui kegiatan wawancara dan observasi di } \\
\text { daerah mitra. }\end{array}$ \\
\hline $\begin{array}{l}\text { Kegiatan } \\
\text { Persiapan }\end{array}$ & $\begin{array}{l}\text { Kegiatan persiapan yakni kegiatan sosialisasi dan koordinasi kepada kepala } \\
\text { desa Wonosari dan ketua PKK desa Wonosari Kecamatan Wonosari Kabupaten } \\
\text { Malang }\end{array}$ \\
\hline Kegiatan & $\begin{array}{l}\text { Kegiatan pelaksanaan terdiri dari kegiatan pelatihan pemasaran. Peserta yang } \\
\text { mengikuti kegiatan ini berjumlah 20 orang warga desa Wonosari Kecamatan } \\
\text { Wonosari Kabupaten Malang. Kegiatan ini dibantu oleh mahasiswa selaku } \\
\text { pembantu teknis dan pengarah pada setiap kelompok kerja. Pada tahap kegiatan } \\
\text { pelatihan disampaikan tentang pentingnya pemasaran, fungsi pemasaran dan } \\
\text { cara serta tips dan trik untuk memasarkan produk. Kegiatan pelatihan } \\
\text { disampaikan oleh pakar dalam bidang pemasaran dan IT. Pada kegiatan ini juga } \\
\text { dilakukan pengembangan pemasaran melaluisecara offline berupa pembuatan }\end{array}$ \\
\hline
\end{tabular}




\begin{tabular}{|l|l|}
\hline & $\begin{array}{l}\text { banner, cara pengemasan yang baik dan brosur, sedangkan pemasaran secara } \\
\text { online dikembangkan social media yang dikhususkan untuk kegiatan pemasaran } \\
\text { produk UKM Telo Ungu gunung Kawi melalui whatsapp, Instagram dan } \\
\text { Facebook. }\end{array}$ \\
\hline $\begin{array}{l}\text { Kegiatan } \\
\text { Evaluasi }\end{array}$ & $\begin{array}{l}\text { Kegiatan evaluasi dilakukan dengan cara monitoring dan evaluasi program } \\
\text { melalui kegiatan pengawasan dan pendampingan terhadap kegiatan pemasaran } \\
\text { UKM Telo Ungu Gunung Kawi. }\end{array}$ \\
\hline
\end{tabular}

\section{Hasil dan Pembahasan}

Hasil kegiatan program kemitraan kepada masyarakat dapat dijabarkan sebagai berikut:

a. Tahap Analisis Kebutuhan

Hasil dari kegiatan analisis kebutuhan diketahui bahwa selama ini kegiatan produksi telah dilakukan oleh masyarakat dengan membentuk UKM Telo Ungu Gunung Kawi. Namun dari hasil analisis kebutuhan diketahui mitra masih mengalami kesulitan dalam hal kegiatan pemasaran, pemasaran warga masih sebatas saudara dan teman di sekitar UKM telo ungu Gunung Kawi.

b. Tahap Persiapan

Pada tahap Persiapan dilakukan kegiatan sosialisasi kegiatan pelatihan pemasaran yang akan dilakukan. Sosialisasi dilakukan kepada kepala desa, ketua PKK dan ketua UKM telo ungu Gunung Kawi. Sosialisasi ini bertujuan untuk meminta izin dan menjabarkan program PKM yang akan diberikan kepada mitra. Hasil dari kegiatan sosialisasi ditunjukkan mitra yang terlibat menyambut baik kegiatan yang akan dilakukan. Mitra memberikan bantuan untuk mensosialisasikan dan memberikan info kegiatan pelatihan pemasaran yang akan dilakukan kepada ibu-ibu PKK yang juga bergerak pada UKM Telo Ungu Gunung Kawi.

Gambar 6. Kegiatan koordinasi dan Sosialisasi dengan kepala desa

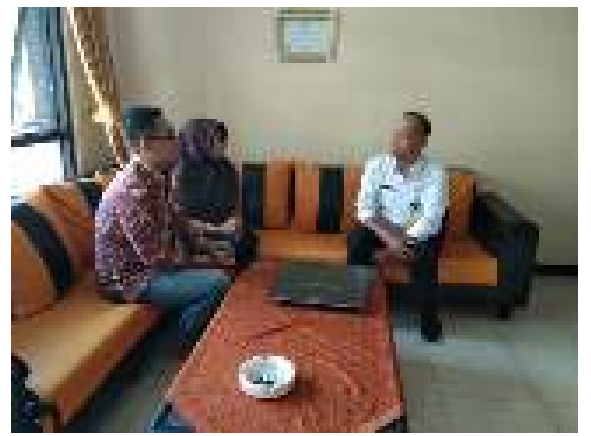

c. Tahap Pelaksanaan

Tahap pelaksanaan dilakukan melalui kegiatan pelatihan pemasaran telo ungu. Kegiatan pelatihan dilakukan dengan mendatangkan pakar pemasaran baik secara 
online dan offline. Kegiatan ini diikuti oleh 20 peserta yang terdiri dari ketua PKK, ketua UKM Telo Ungu Gunung Kawi dan anggota PKK yang juga ikut dalam UKM Telo Ungu Gunung Kawi. Kegiatan ini terbagi menjadi beberapa sesi yakni penjelasan materi, tanya jawab, dan diskusi kelompok perencanaan pemasaran.

Pada tahap penjelasan materi mitra sangat antusias untuk mendengarkan materi yang disampaikan. Materi yang disampaikan oleh pemateri terdiri dari tokoh yang memiliki usaha yang telah sukses, penjelasan tentang konsep pemasaran, fungsi pemasaran, tips dan trik kegiatan pemasaran. Selanjutnya dilanjutkan kegiatan tanya jawab yang dilakukan oleh peserta dan pemateri, disini peserta dan pemateri menganalisis kelemahan-kelemahan yang terjadi selama kegiatan pemasaran. Hasil analisis kelemahan pemasaran selanjutnya dilakukan perencanaan untuk mengatasi peramasalahan yang telah disebutkan sebelumnya.

Perencanaan dilakukan secara berkelompok, 5 orang, dan selanjutnya dilakukan kegiatan presentasi untuk saling diskusi hasil diskusi kelompok. Hasil saling diskusi kelompok didapatkan hasil bahwa 1). Pemasaran akan dilakukan secara offline dengan warga sekitar terlebih dahulu khususnya menyambut idul fitri, 2). Kegiatan pemasaran dilakukan-di rumah warga yaitu ibu BPD yang memiliki lokasi strategis di bawah pesarehan, 3). Kegiatan pemasaran direncanakan dilakukan secara online whatsapp, instagram dan facebook, 4). Rencana jangka panjang akan menentukan titik lokasi di daerah kota misalnya pasar Kepanjen.

Gambar 7. Proses Kegiatan Pelatihan Pemasaran

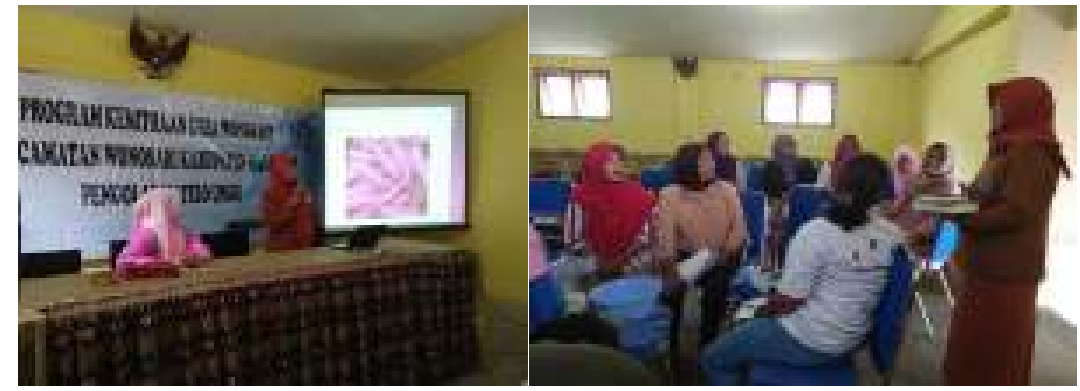

Kegiatan pemasaran terdiri dari beberapa langkah kerja salah satunya adalah kegiatan perencanaan pemasaran. Program perencanaan pemasaran memiliki beberapa manfaat: 1). membantu wiraswastawan berorientasi ke masa depan. Wiraswastawan dipaksa untuk melihat keluar dari masalah harian yang normal untuk memproyeksikan apa yang akan mereka hadapi di masa mendatang, 2). koordinasi keputusan. Keputusan hendaknya tidak dibuat sekarang tanpa adanya gagasan penting bagaimana ini akan 
mempengaruhi keputusan yang harus dibuat besok, 3). perencanaan menekankan tujuan organisasional. Karena tujuan organisasional adalah titik awal perencanaan, wiraswastawan secara konstan diingatkan dengan apa yang ingin dicapai organisasi mereka (Moerdiyanto, 2009).

d. Tahap Evaluasi

Pada tahap evaluasi, dilakukan dengan cara pengawasan dan pendampingan program pemasaran. Pengawasan dilakukan dengan cara pengecekan secara offline melalui media komunikasi dengan UKM Telo Ungu Gunung Kawi, sedangkan secara online dilakukan dengan cara penegcekan kemajuan akun pemasaran yang digunakan. Hasil dari kegiatan pengawasan diketahui pemasaran secara offline sudah cukup digemari oleh konsumen dengan terbukti hampir $20 \mathrm{~kg}$ bahan telah terjual pada konsumen selama satu bulan, sedangkan dalam tahap online masih perlu diberikan motivasi untuk lebih gencar lagi untuk melakukan pemasaran secara online.

Kegiatan pendampingan berdasarkan hasil evaluasi dilakukan kegiatan pendampingan untuk mengatasi permasalahan yang dihadapi oleh mitra. Pada tahap pendampingan mitra menajabarkan permasalahan yang terjadi khususnya pemasaran secara online dan juga pemasaran yang dilakukan di rumah warga belum terlaksana. Namun dari hasil pendampingan terlihat progress yang cukup baik dan didapatkan pemasukan yang cukup besar yakni peningkatan keuntungan sebesar $15 \%$ setelah kegiatan pelatihan dilakukan.

Gambar 8. Proses kegiatan Pendampingan
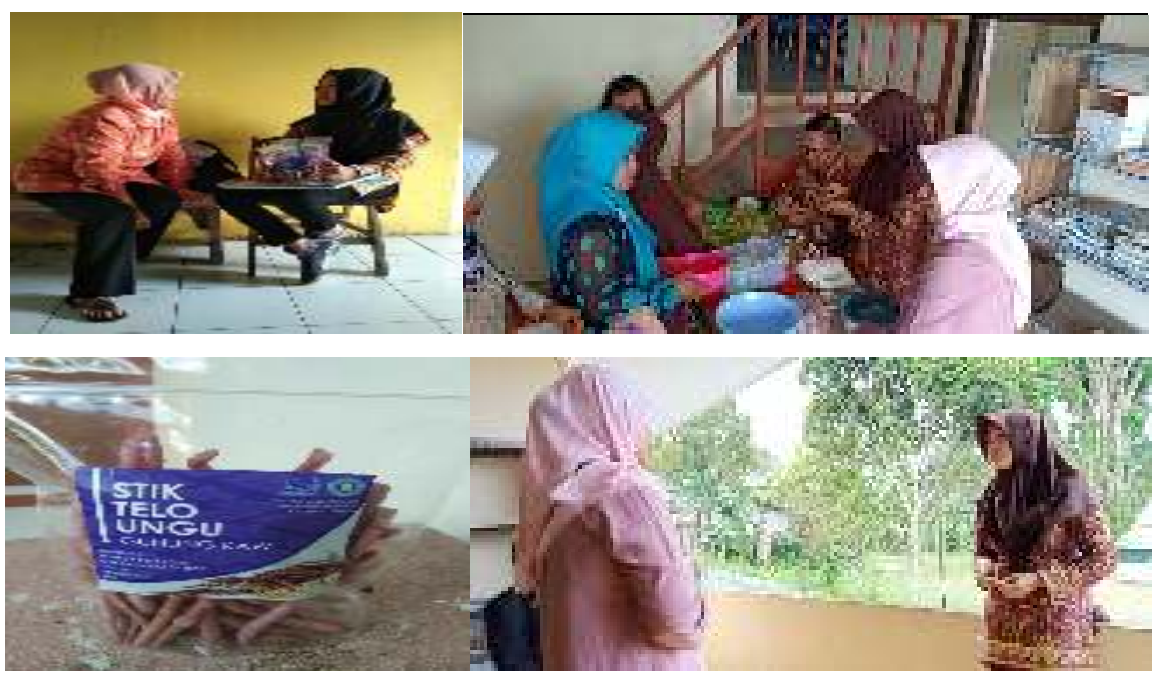
Pendampingan pada hakekatnya merupakan kegiatan membantu, mengarahkan, mendukung terhadap individu/kelompok masyarakat miskin dalam merumuskan masalah, merencanakan, melaksanakan dan melestarikan program pendampingan diperlukan agar potensi yang terdapat dalam masyarakat dapat dikembangkan secara optimal. Manfaat pendampingan adalah untuk menciptakan kemandirian, memberdayakan masyarakat, meningkatkan kemampuan masyarakat, mengembangkan pengawasan sosial, memperluas kesempatan masyarakat, meningkatkan kesejahteraan, dan menjadikan pendampingan sebagai kegiatan professional(Rina Erviyati, 2013) .

\section{Simpulan}

Kegiatan program kemitraan pada masyarakat terdiri dari kegiatan analisis kebutuhan, persiapan, pelaksanaan dan evaluasi program pemasaran. Hasil kegiatan PKM ditunjukkan dengan peningkatan pemasaran UKM secara offline dan online secara lebih luas. Hasil kegitaan PKM ini bertujuan untuk menguatkan UKM Telo Ungu Gunung Kawi khususnya dalam bidang pemasaran yang pada akhirnya dapat meningkatkan omzet UKM. Kegiatan ini juga dapat dijadikan sebagai jembatan kerjasama antara Universitas dengan Mitra dalam mengatasi secara bersama sama permasalahan nyata yang ada pada Masyarakat. Selain itu pada kegiatan ini mahasiswa juga mendapatkan kesempatan untuk mendapatkan pengalaman langsung dalam melaksanakan pengabdian kepada masyarakat.

\section{Ucapan Terima Kasih}

Terima kasih kami sampaikan pada Kemenristekdikti dan Universitas Kanjuruhan yang telah memberikan dukungan secara finansial dan moral atas terselsesainya program kegiatan maysarakat ditahun 2019. Ucapan terima kasih juga kami sampaikan kepada kepala desa Wonosari, Ketua PKK desa Wonosari, Kepala UKM Telo Ungu Gunung Kawi dan Ibu Ibu PKK Desa Wonosari.

\section{Daftar Pustaka}

APJII. (2019). Laporan survey PENETRASI \& PROFIL PERILAKU PENGGUNA INTERNET INDONESIA Survey 2018. Asosiasi Penyelenggara Jasa Internet Indonesia. Polling Indonesia.

Febriani. (2013). Sistem pemasaran dan nilai tambah produk olahan ubi jalar. Skripsi Universitas Yogyakarta. 
Hafsah, M.J. (2004). Upaya Pengembangan Usaha Kecil dan Menengah (UKM). Jurnal Infokop Nomor 25 Tahun XX.

Hidayat, M., W. (2016). 3 Media Sosial Favorit Pengguna Internet Indonesia. Diakses http://tekno.liputan6. com/read/2634027/3-mediasosial-favorit-penggunainternetindonesia.

Jaidan Jauhari. (2010). UPAYA PENGEMBANGAN USAHA KECIL DAN MENENGAH (UKM) DENGAN MEMANFAATKAN E-COMMERCE. 2(1), 159-168.

Maryanti, S. (2017). Manajemen Usaha Kecil. Sleman: Deepublish.

Moerdiyanto. (2009). Diktat Manajemen pemasaran. Yogyakarta: UNY.

Munir, M. (2006). Peran usaha kecil dan menengah ( ukm ) dalam penciptaan lapangan kerja baru. $120-127$.

Kuncoro, Mudrajad, 2008. Tujuh Tantangan UKM di Tengah Krisis Global. Harian Bisnis Indonesia 21 Oktober 2008. [Online] http://www.mudrajad.com/upload/Tujuh\%20 Tantangan\% 20UKM\%20di\%20Tengah\%20Krisis\%20Global.pdf

Kurniawan, Didi. (2009). Mengembangkan Ekonomi Kerakyatan dengan Akselerasi Sektor Riil dan UKM. Tersedia [Online]___ http://didikurniawan.web.id/2009/04/29/ mengembangkan-ekonomi-kerakyatan-dengan-akselerasi-sektor-riil-dan-ukm/.

Kotler P. 2002. Manajemen Pemasaran. Edisi Kesepuluh. Jakarta (ID): PT Prenhalindo

Putri, B. R. T. (2017). Manajemen Pemasaran. In Fakultas Peternakan Universitas Udayana. Retrieved from file://C:/Users/TIKA/Downloads/keil amstrong.pdf

Rina Erviyati. (2013). PENDAMPINGAN PROGRAM KEWIRAUSAHAAN GYPSUM DI DESA VOKASI GESING, KECAMATAN KANDANGAN KABUPATEN TEMANGGUNG SKRIPSI.

Sulistyadi, K., \& Kurniasari, I. R. (2018). PENERAPAN STRATEGI PEMASARAN ONLINE ICE CREAM Abstrak. VII(1), 90-101.

Sulistyo. (2010). PENGEMBANGAN USAHA KECIL DAN MENENGAH DENGAN BASIS EKONOMI KERAKYATAN DI KABUPATEN MALANG. Ekonomi Modernisasi Fakultas Ekonomi - Universitas Kanjuruhan Malang, 6(1), 58-73. 
Supardi, Julian. (2009). Rancang Bangun Collaborative System Pemasaran Hotel Secara online Dengan Pendekatan Mediator based. Jurnal Sistem Informasi Fasilkom Unsri Vol 1 No 2.

Sripo. (2010). 38.044 UKM Serap 163.830 Tenaga Kerja. Harian Umum Sriwijaya Post Tanggal 15 April 2010

Wibowo, D. H., Arifin, Z., \& Sunarti, . (2015). Analisis Strategi Pemasaran Untuk Meningkatkan Daya Saing UMKM (Studi pada Batik Diajeng Solo). Jurnal Administrasi Bisnis, 29(1), 59-66. Retrieved from http://administrasibisnis.studentjournal.ub.ac.id/index.php/jab/article/view/1172

Winarto, H. (2011). Strategi pemasaran. MAJALAH ILMIAH EKONOMIKA, 14(3), 124-128. 